\title{
THE EFFICACY OF SMALL DOSE OF INTRATHECAL NEOSTIGMINE IN MODULATION OF POSTOPERATIVE ANALGESIA AFTER ORTHOPEDIC SURGERY
}

\author{
By \\ Ayman S.H. Rofaeel, MD, Mohamed A. \\ Sultan, MD, Amer A. Attia, MD
}

From

The Department of Anesthesia and Surgical Intensive Care, Faculty of Medicine, Mansoura University, Egypt.

\begin{abstract}
Background: This prospective randomized study was designed to compare the analgesic efficacy and safety of intrathecal (IT) neostigmine, IT morphine, versus IT bupivacaine in patients undergoing lower extremity orthopedic surgery. Methods : The study included sixty patients, 25 to 50 years old, ASA I and II, who were scheduled for lower extremity orthopedic surgery. According to the regimen used for subarachnoid block, patients were randomly assigned to one of three equal groups. The control group received $12.5 \mathrm{mg} 0.5 \%$ bupivacaine. The other groups received either $100 \mu \mathrm{g}$ morphine (morphine group) or $25 \mu \mathrm{g}$ neostigmine (neostigmine group), combined with $12.5 \mathrm{mg} 0.5 \%$ bupivacaine. The onset
\end{abstract}

of sensory and motor blockade, duration of analgesia, and the incidence of postoperative pain were recorded. The adequacy of postoperative analgesia was assessed using pain score. Patients were also observed for adverse effects such as hypotension, bradycardia, nausea and vomiting, pruritus, respiratory depression, dizziness, and headache. Results: The onset of sensory and motor blockade did not differ significantly among the three groups. Compared with the control group, both the morphine and neostigmine groups were similarly associated with significant prolongation of the duration of analgesia $(P<0.01)$, and significant reduction of both the incidence and degree (score) of postoperative pain $(P<0.05)$. Among the studied groups, the incidence of MANSOURA MEDICAL JOURNAL 
nausea and vomiting was similar, but pruritus was significantly more common in the morphine group $(P<0.05)$. No other adverse effects were detected. Conclusion : When combined with bupivacaine spinal anesthesia for orthopedic surgery, the analgesic efficacy of IT neostigmine $(25 \mu \mathrm{g})$ was similar to that of IT morphine $(100 \mu \mathrm{g})$, and better than bupivacaine alone. Pruritus was only observed with IT morphine.

Keywords; Intrathecal neostigmine; intrathecal morphine; postoperative analgesia

\section{INTRODUCTION}

Poor quality of postoperative analgesia is associated with many adverse hemodynamic, respiratory, metabolic, and hemostatic alterations that negatively influence the surgical outcome $(1,3)$. Spinally mediated analgesia can be achieved by several mechanisms. Nonspecific axonal blockade is achieved by local anesthetics, whereas specific blockade of nociception may be accomplished by direct agonists which stimulate specific receptors in the spinal cord, such as opioids and alpha-2 adrenergic agonists(4). Despite the widespread administration of neuraxial morphine Vol. 34, No. 3 \& 4 July., \& Oct, 2003 for management of acute and chronic pain, its side effects such as nausea, vomiting, pruritus, and respiratory depression still represent a major concern(5).

Intrathecal (IT) neostigmine, unlike direct agonists, was reported to produce analgesia through inhibition of the breakdown of spinally released acetylcholine in the dorsal horn ${ }^{(6)}$ and spinal meninges $(7)$. In the spinal cord, acetylcholine-induced analgesia is mediated through a direct action on muscarinic $(8)$ and nicotinic receptors $(9)$, and indirectly through stimulation of the release of nitric oxide(10).

Despite the advances in management of postoperative pain, an optimal analgesic regimen balancing superior antinociceptive efficacy with minimal side effects may be difficult to achieve. In this study, we hypothesized that IT neostigmine, through its dual mechanisms of action on the cholinergic and nitric oxide pathways, may represent a novel approach in achieving optimal postoperative analgesia. The use of a small dose of IT neostigmine $(25 \mu \mathrm{g})$ may also serve to minimize adverse effects. The aim of this prospective study was to evaluate the postoperative analgesic effica- 
cy and safety of IT morphine, IT neostigmine as part of analgesic regimen with IT bupivacaine, versus IT bupivacaine alone in candidates for lower extremity orthopedic surgery.

\section{PATIENTS AND METHODS}

This study included sixty patients of either sex, 25 to 50 years old, and ASA physical status I or II, who were submitted for operative stabilization of femoral fractures at the Emergency Hospital, Mansoura University. The study was approved by the local ethics and research committee, and an informed consent was secured from all patients. The exclusion criteria included the presence of contraindication(s) to spinal anesthesia (e.g., coagulation defects, neurological deficits in the lower extremities, or infection at the puncture site), or known allergy to any of the test drugs. Multiple traumatized or hemodynamically unstable patients $w$ ere also excluded from the study. Preoperative assessment included history, physical examination, and routinely performed laboratory investigations (e.g., complete blood count, coagulation profile, fasting blood glucose, serum creatinine, and liver function tests).

Intravenous (i.v.) line was esta- blished using 18-20 Gauge i.v. cathet$\mathrm{er}$, and all patients received $10 \mathrm{ml} / \mathrm{kg}$ of normal saline $(0.9 \%)$ solution as circulatory preload over 1 hour before spinal anesthesia. Intraoperatively, i.v. infusion of normal saline was maintained at $6-8 \mathrm{ml} / \mathrm{kg} /$ hour. Any blood loss less than $500 \mathrm{ml}$ was further replaced by normal saline giving triple the volume of blood loss, while whole blood was used for replacement if blood loss exceeded $500 \mathrm{ml}$.

Patients were randomized according to sealed envelope assignment to three equal groups (20 patients each); the control group received 12.5 mg bupivacaine, the morphine group received $100 \mu \mathrm{g}$ morphine plus 12.5 mg bupivacaine, whereas the neostigmine group received $25 \mu \mathrm{g}$ neostigmine plus $12.5 \mathrm{mg}$ bupivacaine.

In the control group, $2.5 \mathrm{ml}$ of $0.5 \%$ hyperbaric bupivacaine (equal to $12.5 \mathrm{mg}$ ) was diluted using dextrose $5 \%$ (D5W) to $3 \mathrm{ml}$ volume. Morphine $(10 \mathrm{mg} / 1 \mathrm{ml})$ was diluted to 10 $\mathrm{ml}$ using D5W (1 $\mathrm{ml}=1 \mathrm{mg})$, then 1 $\mathrm{ml}$ of the diluted solution was further diluted to $5 \mathrm{ml}(0.5 \mathrm{ml}=100 \mathrm{ug})$. Neostigmine methylsulfate $(0.5 \mathrm{mg} / 1 \mathrm{ml})$ was diluted to $10 \mathrm{ml}$ using D $5 \mathrm{~W}$ $(0.5 \mathrm{ml}=25 \mathrm{ug})$. In the morphine and MANSOURA MEDICAL JOURNAL 
neostigimine groups, $0.5 \mathrm{ml}$ of the final diluted solution of test drug was mixed with $2.5 \mathrm{ml}$ bupivacaine in the same syringe. The total volume of spinal injectate reached $3 \mathrm{ml}$ in all groups. After proper sterilization and local infiltration anesthesia $(1 \mathrm{ml}$ of $1 \%$ lidocaine) of the skin over the selected lumbar interspace, subarachnoid block was performed using 25 Gauge spinal needle through a midline approach at the L3-4 interspace in the sitting position. Once free flow of clear cerebrospinal fluid was obtained, the test drugs were injected slowly over 30 seconds. The patient was immediately placed in the supine position with elevation of the head 30 degrees and he was maintained in the same position throughout surgery. Supplemental oxygen was delivered through a face mask at a rate of $5 \mathrm{~L} / \mathrm{min}$ during surgery. The onset of sensory block was determined by loss of sensation to pinprick below the $10^{\text {th }}$ thoracic dermatome. The onset of complete motor block was assesed by Bromage scale; $0=$ no paralysis, $1=$ unable to raise the extended leg, but flexes the knee, 2 = unable to flex the knee but flexes the foot, 3 = complete block; unable to move the foot. Intraoperative sedation was achieved by i.v. midazolam (2-3 $\mathrm{mg}$ ). Electrocardiogram (ECG), heart rate $(\mathrm{HR})$, noninvasive blood pressure, oxygen saturation $\left(\mathrm{SpO}_{2}\right)$, and respiratory rate (RR) were continuously monitored throughout the study period. Vital parameters [HR, mean arterial blood pressure (MAP), $\mathrm{SpO}_{2}$, and RR] were recorded at 1 hour preoperatively (basal values), at 5,10 , and 15 minutes after intrathecal injection, and then every 15 minutes till the end of surgery. Intraoperatively, hemodynamic management included increasing the rate of fluid infusion and/ or administration of incremental doses of i.v. ephedrine $(5 \mathrm{mg})$ for hypotension (decrease in the MAP $>20 \%$ below the basal value), and incremental doses of i.v. atropine $(0.2 \mathrm{mg})$ for bradycardia ( $\mathrm{HR}<60$ beats/min).

Arterial carbon dioxide tension $\left(\mathrm{PaCO}_{2}\right)$ and arterial oxygen tension $\left(\mathrm{PaO}_{2}\right)$ were checked through arterial blood gas measurement, which was performed initially at 1 hour preoperatively, and 1 hour intraoperatively. It was then repeated if a decrease in respiratory rate (< 10 breaths $/ \mathrm{min}$ ) and/or $\mathrm{SpO}_{2}(<90 \%)$ was recorded at any time during follow up. Postoperatively, vital parameters were recorded and pain score was assessed at intervals of $1,2,3,6,12,18$, and 24 hours. 
The degree of postoperative pain was scored as: no pain $=0$, very mild $=1$, mild $=2$, moderate $=3$, severe $=4$, and intolerable $=5$ (11). The duration of analgesia was recorded as the time from the onset of sensory blockade till the patient's first request for rescue analgesia, which was provided by nonsteriodal anti-inflammatory drugs (intramuscular diclofenac $75 \mathrm{mg}$ ). Throughout the study period, the incidence of adverse effects such as nausea, vomiting, pruritus, respiratory depression (respiratory rate < 10 breaths/min), dizziness, and headache was recorded. Vomiting was treated with i.v. metoclopramide (10 $\mathrm{mg})$, whereas pruritus was treated with i.v. nalburhine ( $3 \mathrm{mg}$ ).

\section{Statistical Analysis :}

Data were analyzed using Statistical Package for Social Science (SPSS, version 9), and were expressed as mean $\pm S D$, median (range), or frequency (\%) as appropriate. Continuously distributed values were analyzed using one way ANOVA (for comparison between mean values of the three groups) or repeated measure ANOVA (for intragroup comparison), followed by Bonferroni correction if significance was detected. Kruskal-Wallis test was used to analyze differences in pain score among the studied groups, while the incidence of adverse effects was analyzed using Fisher's exact test. A probability $(P)$ value $<0.05$ was considered to be statistically significant.

\section{RESULTS}

The patients' characteristics, duration of surgery, and the onset of sensory and motor blockade did not differ significantly among the studied groups (tables $1 \& 2$ ).

Intraoperatively, HR decreased significantly from the basal value at 10 and 15 minutes in the control and morphine groups, and at 10 minutes in the neostigmine group ( $P<0.05$; figure 1). Similarly, MAP decreased significantly from the basal value at 5 , 10 , and 30 minutes in the control group, at 15 and 30 minutes in the morphine group, and at 10 minutes in the neostigmine group ( $P<0.05$; figure 2). However, neither a decrease in HR below 60 beats/min nor a decrease in MAP more than $20 \%$ from the basal value was encountered allover the monitoring period (table 5). 
Throughout the study period, recordings of $\mathrm{RR}, \mathrm{SpO}_{2}, \mathrm{PaCO}_{2}$ and $\mathrm{PaO}_{2}$ remained within their physiologic limits in all groups.

The duration of analgesia was significantly longer in both the morphine and neostigmine groups (12.1 \pm 1.7 and $11.8 \pm 2.1$ hours respectively) as compared with the control group (4.6 \pm 0.7 hours) $(P<0.01$; table 2$)$. The incidence of postoperative pain was significantly higher in the control group than in the morphine and neostigmine groups till 18 hours postoperatively ( $P<0.05$; table 3 ). All patients in both the morphine and the neostigmine groups were pain-free up to 6 hours postoperatively, when only one patient out of each group started to suffer very mild pain (pain score of 1). The incidence of postoperative pain then increased progressively over the subsequent follow up intervals till 24 hours postoperatively, when no significant difference among the three studied groups could be detected. Moreover, there was a significant reduction in pain score in both the morphine and neostigmine groups as compared with the control group from 1 hour till 18 hours postoperatively ( $P<0.05$; table 4 ). At 24 hours postoperatively, pain scores did not differ significantly among the three groups. Throughout the postoperative period, both the morphine and neostigmine groups did not differ significantly as regards either the pain score or the incidence of pain.

The incidence of nausea and vomiting did not differ significantly among the studied groups. However, the incidence of pruritus was significantly higher in the morphine group than in the other groups $(P<0.05)$. Respiratory depression, dizziness, or headache was not observed in any of the studied groups (table 5). 
Table 1. Patients characteristics and duration of surgery in the studied groups.

\begin{tabular}{cccc}
\hline & $\begin{array}{c}\text { Control group } \\
(\mathrm{n}=20)\end{array}$ & $\begin{array}{c}\text { Morphine group } \\
(\mathrm{n}=20)\end{array}$ & $\begin{array}{c}\text { Neostigmine } \\
\text { group }(\mathrm{n}=20)\end{array}$ \\
\hline Age (years) & $35.8 \pm 8.9$ & $36.1 \pm 9.5$ & $35.4 \pm 7.9$ \\
Gender $(\mathrm{m} / \mathrm{f})$ & $13 / 7$ & $11 / 9$ & $10 / 10$ \\
Weight $(\mathrm{kg})$ & $75.6 \pm 5.9$ & $74.1 \pm 7$ & $73.5 \pm 8.1$ \\
Height $(\mathrm{cm})$ & $170.7 \pm 7.5$ & $171.8 \pm 14$ & $172.8 \pm 10$ \\
Duration of surgery $(\mathrm{min})$ & $119.3 \pm 23.2$ & $120.8 \pm 22.5$ & $114.8 \pm 22.9$ \\
\hline
\end{tabular}

Values are expressed as mean \pm SD.

Table 2. Characteristics of spinal anesthesia in the studied groups.

\begin{tabular}{cccc}
\hline & $\begin{array}{c}\text { Control group } \\
(\mathrm{n}=20)\end{array}$ & $\begin{array}{c}\text { Morphine group } \\
(\mathrm{n}=20)\end{array}$ & $\begin{array}{c}\text { Neostigmine group } \\
(\mathrm{n}=20)\end{array}$ \\
\hline Onset of sensory block (min) & $4.1 \pm 0.3$ & $3.8 \pm 0.3$ & $4 \pm 0.2$ \\
Onset of motor block (min) & $5 \pm 0.4$ & $4.9 \pm 0.5$ & $5.2 \pm 0.2$ \\
Duration of analgesia (hours) & $4.6 \pm 0.7$ & $12.1 \pm 1.7^{*}$ & $11.8 \pm 2.1^{*}$ \\
Range & $(3.6-5.4)$ & $(10.2-14.8)$ & $(9.5-14.3)$ \\
\hline
\end{tabular}

Values are expressed as mean \pm SD.

* Significant difference in both the morphine and neostigmine groups in comparison with the control group $(P<0.01)$.

Table 3. The incidence of postoperative pain in the studied groups.

\begin{tabular}{cccc}
\hline Postoperative time & $\begin{array}{c}\text { Control group } \\
(\mathrm{n}=20)\end{array}$ & $\begin{array}{c}\text { Morphine group } \\
(\mathrm{n}=20)\end{array}$ & $\begin{array}{c}\text { Neostigmine group } \\
(\mathrm{n}=20)\end{array}$ \\
\hline $1 \mathrm{~h}$ & $17(85 \%)^{*}$ & $0(0 \%)$ & $0(0 \%)$ \\
$2 \mathrm{~h}$ & $20(100 \%)^{*}$ & $0(0 \%)$ & $0(0 \%)$ \\
$3 \mathrm{~h}$ & $20(100 \%)^{*}$ & $0(0 \%)$ & $0(0 \%)$ \\
$6 \mathrm{~h}$ & $20(100 \%)^{*}$ & $1(5 \%)$ & $1(5 \%)$ \\
$12 \mathrm{~h}$ & $20(100 \%)^{*}$ & $12(60 \%)$ & $11(55 \%)$ \\
$18 \mathrm{~h}$ & $20(100 \%)^{*}$ & $14(70 \%)$ & $15(75 \%)$ \\
$24 \mathrm{~h}$ & $20(100 \%)$ & $19(95 \%)$ & $20(100 \%)$ \\
\hline
\end{tabular}

Values are expressed as number and percentage (\%).

* Significant difference in the control group in comparison with both the morphine and neostigmine groups $(P<0.05)$. 
Table 4. Postoperative pain score in the studied groups.

\begin{tabular}{cccc}
\hline Postoperative time & $\begin{array}{c}\text { Control group } \\
(\mathrm{n}=20)\end{array}$ & $\begin{array}{c}\text { Morphine group } \\
(\mathrm{n}=20)\end{array}$ & $\begin{array}{c}\text { Neostigmine group } \\
(\mathrm{n}=20)\end{array}$ \\
\hline $1 \mathrm{~h}$ & $2(0-2)$ & $0(0-0)^{*}$ & $0(0-0)^{*}$ \\
$2 \mathrm{~h}$ & $2(1-4)$ & $0(0-0)^{*}$ & $0(0-0)^{*}$ \\
$3 \mathrm{~h}$ & $3(2-4)$ & $0(0-0)^{*}$ & $0(0-0)^{*}$ \\
$6 \mathrm{~h}$ & $4(3-4)$ & $0(0-1)^{*}$ & $0(0-1)^{*}$ \\
$12 \mathrm{~h}$ & $4(4-4)$ & $1(0-2)^{*}$ & $1(0-3)^{*}$ \\
$18 \mathrm{~h}$ & $4(4-4)$ & $2(0-2)^{*}$ & $2(1-3)^{*}$ \\
$24 \mathrm{~h}$ & $4(4-4)$ & $3(0-3)$ & $3(1-3)$ \\
\hline
\end{tabular}

Values are expressed as median (range).

* Significant difference in both the morphine and neostigmine groups in comparison with the control group $(P<0.05)$.

Table 5. The incidence of adverse effects in the studied groups.

\begin{tabular}{cccc}
\hline & $\begin{array}{c}\text { Control group } \\
(\mathrm{n}=20)\end{array}$ & $\begin{array}{c}\text { Morphine group } \\
(\mathrm{n}=20)\end{array}$ & $\begin{array}{c}\text { Neostigmine group } \\
(\mathrm{n}=20)\end{array}$ \\
\hline Nausea and vomiting & $1(5 \%)$ & $2(10 \%)$ & $2(10 \%)$ \\
Pruritus & $0(0 \%)$ & $4(20 \%)^{*}$ & $0(0 \%)$ \\
Bradycardia $^{5}$ & $0(0 \%)$ & $0(0 \%)$ & $0(0 \%)$ \\
Hypotension $^{5}$ & $0(0 \%)$ & $0(0 \%)$ & $0(0 \%)$ \\
Respiratory depression $_{\text {Dizziness }}$ & $0(0 \%)$ & $0(0 \%)$ & $0(0 \%)$ \\
Headache & $0(0 \%)$ & $0(0 \%)$ & $0(0 \%)$ \\
& $0(0 \%)$ & $0(0 \%)$ & $0(0 \%)$
\end{tabular}

Values are expressed as number and percentage (\%).

'Bradycardia; heart rate $<60$ beats/min.

'Hypotension; decrease in MAP $>20 \%$ of its basal value.

* Significant difference in the morphine group as compared with the other groups $(P<0.05)$. 
Ayman S.H. Rofaeel et al .....

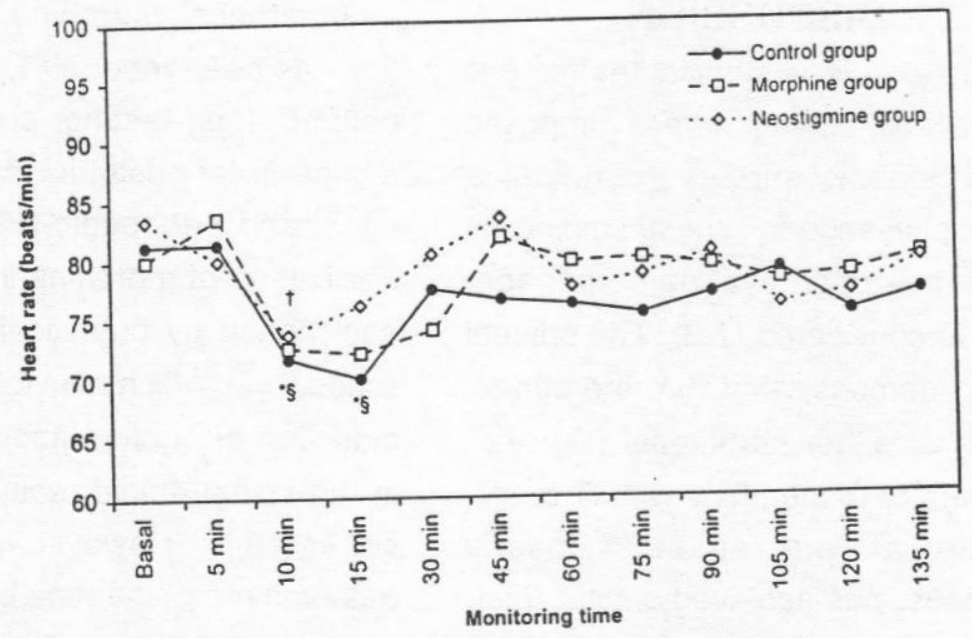

Figure 1. Intraoperative changes in heart rate Basal value; 1 hour preoperatively

Significant difference from the basal value in the control ${ }^{*}$, morphine§, and neostigmine ${ }^{+}$groups $(\mathrm{P}<0.05)$.

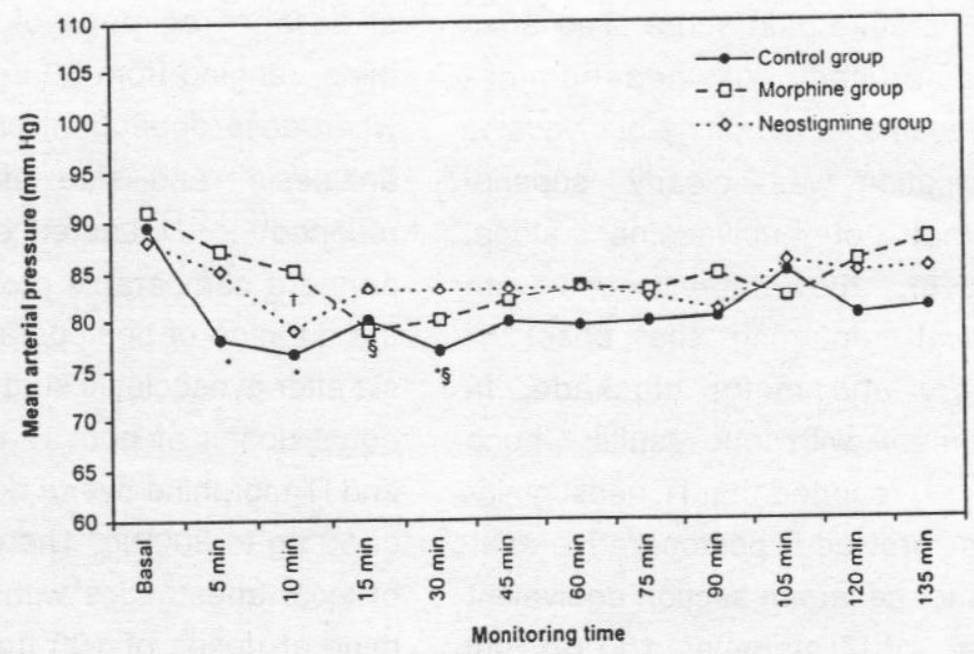

Figure 2. Intraoperative changes in mean arterial blood pressure Basal value; 1 hour preoperatively

Significant difference from the basal value in the control ${ }^{*}$, morphine, and neostigmine ${ }^{+}$groups $(P<0.05)$. 


\section{DISCUSSION}

The extensive surgical trauma and the overwhelming stress imposed by orthopedic surgery represent a major challenge for anesthesiologists when postoperative pain management is considered (1-3). The present study demonstrated that the combination of either intrathecal (IT) neostigmine or IT morphine with IT bupivacaine at the studied dosage regimens, has achieved similar analgesic efficacy. This was evident through a comparable prolongation of the duration of analgesia, and reduction of both the incidence of postoperative pain and degree of postoperative pain score. The analgesic efficacy of neostigminebupivacaine or morphine-bupivacaine combination was clearly superior to that of bupivacaine alone. However, the three groups were identical regarding the onset of sensory and motor blockade. In agreement with our results, Chung et al(12), reported that IT neostigmine $25 \mu \mathrm{g}$ provided postoperative analgesia for cesarean section equivalent to that of IT morphine $100 \mu \mathrm{g}$, but neither IT morphine nor IT neostigmine was shown to fasten the onset of sensory and motor blockade from bupivacaine anesthesia $(12,13)$.
Intrathecal morphine administration has been reported to provide excellent, long-lasting postoperative analgesia for obstetric $(14,15)$, urologic (16) and orthopedic procedures $(5)$. Facilitation of morphine-induced antinociception by bupivacaine was described (17), which may result from the induction of conformational changes in the spinal opioid receptors by bupivacaine $(18)$. However, the use of intrathecal morphine may be limited by a frequent incidence of side effects, especially delayed respiratory depression and pruritus (19).

Previous studies have used several dosage regimens of IT neostigmine, ranging from $50 \mu \mathrm{g}$ to $750 \mu \mathrm{g}$, when dose dependant postoperative analgesia and side effects were reported $(20,21)$. Lauretti et al(22), reported a comparable prolongation of the duration of postope:ative analgesia after gynecologic surgery between equal doses of both IT neostigmine and IT morphine over a dosage range of $50 \mathrm{ug}$ to $200 \mathrm{ug}$. The combination of local anesthetics with IT neostigmine at doses of $100 \mu \mathrm{g}^{(23)}$ and 50 $\mu \mathrm{g}^{(24)}$ was reported to prolong the duration of sensory and motor blockade, and to provide longer duration of analgesia, although increased the inci- 
dence of side effects.

However, high doses of IT neostigmine $(>100 \mu \mathrm{g})$ were reported to produce many adverse effects such as an increase in blood pressure and heart rate, severe nausea and vomiting, motor weakness, sedation, and reduction in deep tendon reflexes(20).

Based on the dosage scale previously investigated for both IT morphine and IT neostigmine, relatively small doses of both drugs $(100 \mu \mathrm{g}$ and $25 \mu \mathrm{g}$ respectively) were selected in this study, in order to improve their safety profile.

The enhanced analgesic efficacy of neostigmine in postoperative setting was proposed to result from greater release of spinal acetylcholine from the intense and more prolonged discomfort of postoperative pain, which activates a preexistant spinal cholinergic tonus. Furthermore, acetylcholine preserved after IT neostigmine administration will leac to an increased total concentration of acetylcholine in the cerebrospinal fluid (CSF), and an improved bioavailability at muscarinic and nicotinic nerve terminals in the spinal cord (13).
Pharmacokinetic studies demonstrated that CSF neostigmine concentrations, even after the lowest doses of spinal neostigmine, were adequate to significantly inhibit cholinestrase in CSF, allowing sustained plateau of increased acetylcholine concentration in CSF, and thus produce analgesia in the lower extremities(25).

Further analgesic effect of IT neostigmine involves stimulation of the synthesis of nitric oxide in the dorsal horn neurons that contain choline acetyltransferase $(26,27)$, and in the intermediolateral cell column regions of the spinal cord where muscarinic receptors have been identified $(28,29)$. Lauretti et al (13), suggested that nitric oxide and IT neostigmine enhances each other's antinociceptive effects.

The augmentation of spinal bupivacaine with a small dose of neostigmine may be benificial in the surgical settings because IT neostigmine may have greater analgesic effects in that situation (24). It is also speculated that the increased spinal levels of acetylcholine may augment motor blockade from spinal bupivacaine. Since IT neostigmine was reported to prolong the duration of motor blockade, it could be argued 
that such effect might limit its clinical usefulness in outpatient spinal anesthesia $(23,24)$. Nevertheless, neostigmine-enhanced motor blockade may be useful in some clinical settings, such as lower extremity surgical procedures which require profound muscle relaxation that may not be achievable with IT bupivacaine alone $(24,30)$. Since lower extremity orthopedic procedures are usually performed as inpatient procedures, and as IT neostigmine is more efficient for relief of somatic rather than visceral pain (31), the combination of IT neostigmine with IT bupivacaine seems to provide satisfactory analgesia after orthopedic surgery.

In the present study, few recordings of statistically significant decrease in heart rate (HR) and mean arterial pressure (MAP) from basal values were encountered intraoperatively in the three groups. However, these recordings were considered to be clinically irrelevant, since they still remained within the physiologic limits of both $H R$ and MAP. Furthermore, the predetermined levels of bradycardia or hypotension that mandate intervention were not encountered throughout the monitoring period.

Vol. 34, No. 3 \& 4 July., \& Oct, 2003
The functional sympathectomy induced by IT bupivacaine represents a major precipitating factor for hypotension (32). Following IT morphine administration, hypotension may not be uncommon, and is probably attributed to the existence of opioid receptors on the preganglionic sympathetic nerves, the blockade of which can reduce the sympathetic activity (33). Neverthless, neostigmine was reported to increase the activity of preganglionic sympathetic neurons in the spinal cord, and to counteract the sympatholytic effects of spinal anesthesia (20). However, this cardiovascular stimulatory effect is evident only with large doses of IT neostigmine $(>150 \mu \mathrm{g})(20,24)$. Moreover, it was reported that small doses of IT neostigmine $(<100 \mu \mathrm{g})$ may not even prevent local anesthetic-induced hypotension (34-36).

In agreement with these reports, the use of much smaller dose of neostigmine $(25 \mu \mathrm{g})$ in our study probably explains the lack of the stimulatory effect of neostigmine on hemodynamics during spinal anesthesia.

In the studied groups, no evidence of respiratory depression was detected, as indicated by the virtually un- 
changed levels of respiratory rate, oxygen saturation, arterial carbon dioxide tension, and arterial oxygen tension from preoperative values. In accordance with our study, previous studies found no respiratory depressant effect with doses of IT morphine < $200 \mu \mathrm{g}(37)$ or with IT neostigmine (12). Nevertheless, IT neostigmine may have a respiratory stimulant effect due to stimulation of the pontine centers of respiratory control from cephalad distribution (38)

In this study, the incidence of nausea and vomiting did not differ significantly among the studied groups, which may be attributed to the use of small doses of IT morphine and neostigmine $(100 \mu \mathrm{g}$ and $25 \mu \mathrm{g}$ respectively). In contrast with our results, Chung et al (12), reported an increased incidence of nausea and vomiting with IT neostigmine $25 \mu \mathrm{g}$ in term parturients. This discrepancy may be explained by the difference in patients' population. Pregnancy is associated with higher potential for cephalad spread of neuraxially injected drugs (39-41), and subsequently increases the incidence of adverse effects $(42,43)$. Moreover, the preparation of both morphine and neostigmine in a dextrose-containing solution, and maintenance of patients in the sitting position during spinal injection and in a head up position throughout surgery probably contributed to the reduced incidence of nausea and vomiting in our study. These factors were reported to minimize adverse effects through limiting cephalad migration of spinally injected drugs $(20,44)$.

Similar to other adverse effects due to IT morphine or neostigmine administration, nausea and vomiting were reported to occur in a dosedependent manner (45). Significantly increased incidence of nausea and vomiting was previously described in association with large doses of both IT morphine $(>200 \mu \mathrm{g})(46,47)$, and IT neostigmine $(>50 \mu \mathrm{g})(44,48)$.

The incidence of pruritus was higher in the morphine group, in comparison with the neostigmine and control groups. Despite the attemps done to limit central migration of the test drugs $(20,44)$, pruritus represented an inevitable adverse effect following IT morphine administration in some of the studied patients. In accordance with our results, higher incidence of pruritus was described in association with a similar dose of IT morphine 
$(100 \mu \mathrm{g})$ than with either IT neostigmine $(25 \mu \mathrm{g})$ or IT bupivacaine (12 $\mathrm{mg}$ ) (12).

Pruritus was reported as one of the most frequent side effects following IT morphine administration (19), especially with doses $>200 \mu \mathrm{g}$ $(14,49)$. The mechanism of pruritus may not be fully understood. It is probably not related to histamine release, as histamine antagonists are ineffective in the therapy of pruritus following IT morphine (50). The activation of mu receptors in the substantia gelatinosa of the spinal cord's dorsal horn may be responsible for pain modulation and other side effects, especially pruritus (51). This may explain the antipruritic effect of nalbuphine, a specific mu receptor antagonist (49).

In the present study, a commercially available neostigmine preparation containing methyl and propylparabens as antioxidants was used. Previous experimental and human testing of paraben-containing neostigmine in a dextrose solution failed to demonestrate any behavioural or histopathological evidence of neurotoxicity after spinal administration $(24,48)$.

In conclusion, the combination of small dose of neostigmine $(25 \mu \mathrm{g})$ with spinal bupivacaine anesthesia appears to provide an optimally improved postoperative analgesia after orthopedic procedures. The analgesic efficacy of IT neostigmine $(25 \mu \mathrm{g})$ was comparable to that of IT morphine $(100 \mu \mathrm{g})$, and both were superior to bupivacaine alone. The absence of pruritis following IT neostigmine is advantageous, as compared with IT morphine.

\section{REFERENCES}

1. Kehlet H (1989) : Surgical stress: the role of pain and analgesia. $\mathrm{Br} J$ Anaesth 63 : 189-95.

2. Weissman C (1990): The metabolic response to stress: an overview and update. Anesthesiology 73:308-27.

3. Liu S, Carpenter RL, Neal JM (1995) : Epidural anesthesia and analgesia. Their role in postoperative outcome. Anesthesiology 82:1474506.

4. Naguib M, Yaksh TL (1994) : Antinociceptive effects of spinal cholinesterase inhibi- 
tion and isobolographic analysis of the interaction with mu and alpha 2 receptor systems. Anesthesiology 80:1338-48.

5. Fournier R, Van Gessel E, Macksay M, Gamulin Z (2000) : Onset and offset of intrathecal morphine versus nalbuphine for postoperative pain relief after total hip replacement. Acta Anaesthesiol Scand 44:940-5.

\section{Abram SE, Winne RP (1995) :} Intrathecal acetyl cholinesterase inhibitors produce analgesia that is synergistic with morphine and clonidine in rats. Anesth Analg 81:501-7.

7. Ummenhofer WC, Brown SM, Bernards CM (1998) : Acetylcholin-esterase and butyrylcholinesterase are expressed in the spinal meninges of monkeys and pigs. Anesthesiology 88: 1259-65.

8. Iwamoto ET, Marion L (1993) : Characterization of the anti- nociception produced by intrathecally administered muscarinic agonists in rats. $\checkmark$ Pharmacol Exp Ther 266:329-38.

9. Chiari A, Eisenach JC (1998) : Spinal anesthesia: mechanisms, agents, methods, and safety. Reg Anesth Pain Med 23:357-62

10. Xu Z, Li P, Tong C, et al (1996): Location and characteristics of nitric oxide synthase in sheep spinal cord and its interaction with alpha(2)adrenergic and cholinergic antinociception. Anesthesiology 84:890-9.

\section{Samii $K$, Chauvin $M$, Viars $P$} (1981) : Postoperative spinal analgesia with morphine. $\mathrm{Br}$ J Anaesth 53:817-20.

12. Chung CJ, Kim JS, Park HS, Chin YJ (1998): The efficacy of intrathecal neostigmine, intrathecal morphine, and their combination for post-cesarean section analgesia. Anesth Analg 87:341-6.

MANSOURA MEDICAL JOURNAL 
THE EFFICACY OF SMALL DOSE OF INTRATHECAL etc.

13. Lauretti GR, Oliveira AP, Juliao MC, et al (2000) : Transdermal nitroglycerine enhances spinal neostigmine postoperative analgesia following gynecological surgery. Anesthesiology 93:943-6.

14. Abboud TK, Dror A, Mosaad P, et al (1988) : Mini-dose intrathecal morphine for the relief of post-cesarean section pain: safety, efficacy, and ventilatory responses to carbon dioxide. Anesth Analg 67:137-43.

15. Culebras X, Gaggero G, Zatloukal J, et al (2000) : Advantages of intrathecal nalbuphine, compared with intrathecal morphine, after cesarean delivery: an evaluation of postoperative analgesia and adverse effects. Anesth Analg 91:601-5.

16. Kirson LE, Gcldman JM, Slover RB (1989) : Low-dose intrathecal morphine for postoperative pain control in patients undergoing transurethral resection of the prostate. Anesthesiology
71:192-5.

17. Bachmann M, Laakso E, Niemi L, et al (1997) : Intrathecal infusion of bupivacaine with or without morphine for postoperative analgesia after hip and knee arthroplasty. Br J Anaesth 78:666-70.

18. Tejwani GA, Rattan AK, McDonald JS (1992) : Role of spinal opioid receptors in the antinociceptive interactions between intrathecal morphine and bupivacaine. Anesth Analg 74:726-34.

19. Abouleish E, Rawal N, Shaw J, et al (1991) : Intrathecal morphine $0.2 \mathrm{mg}$ versus epidural bupivacaine $0.125 \%$ or their combination: effects on parturients. Anesthesiology 74:711-6.

20. Hood DD, Eisenach JC, Tuttle R (1995) : Phase I safety assessment of intrathecal neostigmine methylsulfate in humans. Anesthesiology 82:331-43.

21. Lauretti GR, Reis MP (1997) :

Vol. 34, No. 3 \& 4 July., \& Oct, 2003 
Postoperative analgesia and antiemetic efficacy after subarachnoid neostigmine in orthopedic surgery. Reg Anesth 22:337-42.

22. Lauretti GR, Reis MP, Prado WA, Klamt JG (1996) : Dose-response study of intrathecal morphine versus intrathecal neostigmine, their combination, or placebo for postoperative analgesia in patients undergoing anterior and posterior vaginoplasty. Anesth Analg 82:1182-7.

23. Tan $\mathrm{PH}$, Kuo JH, Hung CC, et al (2000) : Efficacy of intrathecal neostigmine for the relief of postinguinal herniorrhaphy pain. Acta Anesthesiol Scand 44:1056-60

24. Liu SS, Hodgson PS, Moore JM, et al (1999) : Doseresponse effects of spinal neostigmine added to bupivacaine spinal anesthesia in volunteers. Anesthesiology 90:710-7.

25. Shafer SL, Eisenach JC, Hood
DD, Tong C (1998) : Cerebrospinal fluid pharmacokinetics and pharmacodynamics of intrathecal neostigmine methylsulfate in humans. Anesthesiology 89:1074-88.

26. Feldman DS, Terry AV Jr, Buccafusco JJ (1996) : Spinal muscarinic cholinergic and nitric oxide systems in cardiovascular regulation. Eur J Pharmacol 17;313:211-20.

27. Xu Z, Tong C, Eisenach JC (1996) : Acetylcholine stimulates the release of nitric $\mathrm{cx}$ ide from rat spinal cord. Anesthesiology 85:107-11.

28. Terenghi G, Riveros-Moreno V, Hudson LD, et al (1993) : Immuno-histochemistry of nitric oxide synthase demonstrates immunoreactive neurons in spinal cord and dorsal root ganglia of man and rat. $J$ Neurol Sci 118:34-7.

29. Villiger JW, Faull RL (1985) : Muscarinic cholinergic receptors in the human spinal MANSOURA MEDICAL JOURNAL 
cord: differential localization of [3H] pirenzepine and [3H] quinuclidinylbenzilate binding sites. Brain Res 345:196-9.

30. Liu SS, Ware PD, Allen HW, et al (1996) : Dose-response characteristics of spinal bupivacaine in volunteers. Clinical implications for ambulatory anesthesia. Anesthesiology 85:729-36.

31. Lauretti GR, Lima IC (1996) : The effects of intrathecal neostigmine on somatic and visceral pain : improvement by association with a peripheral anticholinergic. Anesth Analg 82:617-20.

32. Riley ET, Walker D, Hamilton CL, Cohen SE (1997) : Intrathecal sufentanil for labor analgesia does not cause a sympathectomy. Anesthesiology $87: 874-8$.

33. Romagnano MA, Hamill RW (1984) : Spinal sympathetic pathway: an enkephalin ladder. Science 225:737-9.
34. Lauretti GR, Reis MP (1996) : Subarachnoid neostigmine does not affect blood pressure or heart rate during bupivacaine spinal anesthesia. Reg Anesth 21:586-91.

35. Klamt JG, Slullitel A, Garcia IV, Prado WA (1997) : Postoperative analgesic effect of intrathecal neostigmine and its influence on spinal anaesthesia. Anaesthesia 52:547-51.

36. Krukowski JA, Hood DD, Eisenach JC, et al (1997) : Intrathecal neostigmine for post-cesarean section analgesia: dose response. Anesth Analg 84:1269-75.

37. Gerancher JC, Floyd H, Eisenach J (1999) : Determination of an effective dose of intrathecal morphine for pain relief after cesarean delivery. Anesth Analg 88:346-51.

38. Elmalem E, Chorev M, Weinstock M (1991) : Antagonism of morphine- 
induced respiratory depression by novel anticholinesterase agents. Neuropharmacology 30:1059-64.

39. Hirabayashi $Y$, Shimizu $R$, Saitoh K, et al (1996) : Acid-base state of cerebrospinal fluid during pregnancy and its effect on spread of spinal anaesthesia. $\mathrm{Br} J$ Anaesth 77:352-5.

40. Hirabayashi $Y$, Shimizu R, Fukuda H, et al (1995) : Anatomical configuration of the spinal column in the supine position. II. Comparison of pregnant and nonpregnant women. $\mathrm{Br} J$ Anaesth 75:6-8.

\section{Igarashi T, Hirabayashi Y,} Shimizu R, et al (2000) : The fiberscopic findings of the epidural space in preg. nant women. Anesthesiology 92:1631-6.

42. Musch G, Liposky J (1999) : Dysphagia following intrathecal local anestheticopioid administration.J Clin Anesth 11:413-5.
43. Sayyid SS, Jabbour DG, Baraka AS (2003) : Hypothermia and excessive sweating following intrathecal morphine in a parturient undergoing cesarean delivery. Reg Anesth Pain Med 28:140-3.

44. Owen MD, Ozsarac O, Sahin S, Uckunkaya N (2000) : Lowdose clonidine and neostigmine prolong the duration of intrathecal bupivacainefentanyl for labor analgesia. Anesthesiology 92:361-6.

45. Tan $\mathrm{PH}$, Liu $\mathrm{K}$, Peng $\mathrm{CH}$, et al (2001) : The effect of dexamethasone on postoperative pain and emesis after intrathecal neostigmine. Anesth Analg 92:228-32.

46. Grattidge $P$ (1998) : Nausea and vomiting after major arthroplasty with spinal anaesthesia including morphine: a randomized trial of subhypnotic propofol infusion as prophylaxis. Acta Anaesthesiol Scand 42:124-7.

47 Husaini SW, Russell IF (1998) : Intrathecal diamorphine MANSOURA MEDICAL JOURNAL 
compared with morphine for postoperative analgesia after caesarean section under spinal anaesthesia. $\mathrm{Br} J$ Anaesth 81:135-9.
(2001) : Nalbuphine versus propofol for treatment of intrathecal morphine-induced pruritus after cesarean delivery. Anesth Analg 93:162-5.
48. Eisenach JC, Hood DD, Curry R (1997) : Phase I human safety assessment of intrathecal neostigmine containing methyl- and propylparabens. Anesth Analg 85:842-6.

49. Charuluxananan S, Kyokong $O$, Somboonviboon $\mathrm{W}$, et al
50. Krause L, Shuster S (1983): Mechanism of action of antipruritic drugs. Br Med J (Clin Res Ed) 287:1199-200.

51. Bromage PR, Camporesi EM, Durant PA, Nielsen $\mathrm{CH}$ (1982) : Rostral spread of epidural morphine. Anesthesiology 56:431-6. 


\section{كفاءة حقن جرعة صغيرة من النيوستجمين داخل الغمد الشوكى فى تعديل تسكين الألم بعد جراحة العظام}

صمت هذه الدراسة لمقارنة إستخدام عقارى النيوستجمين والمورفين بحقنهـا داخل الغمد الشوكى مع عقار الببيبيفاكين لتسكين آلام مابعد عمليات جراحات العظام للطرنبين السفليين ـ أجريت هذه الدراسة

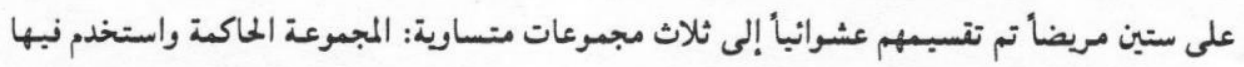

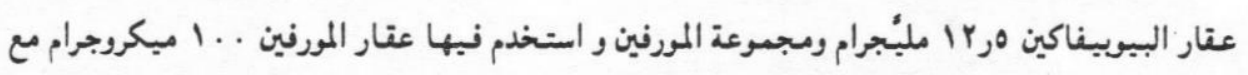

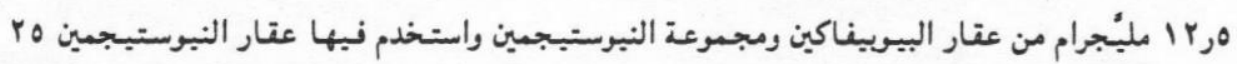

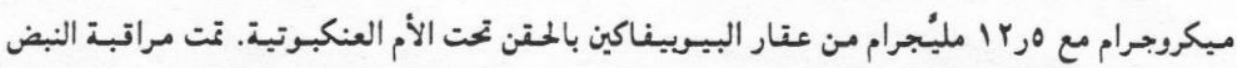

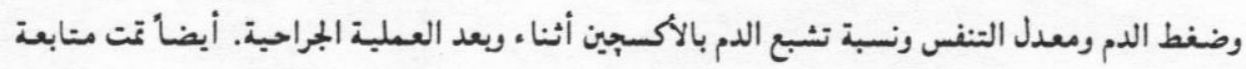

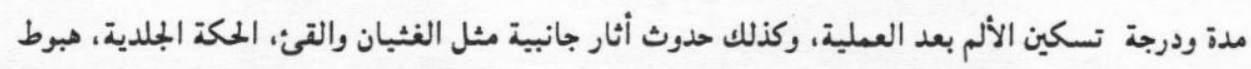

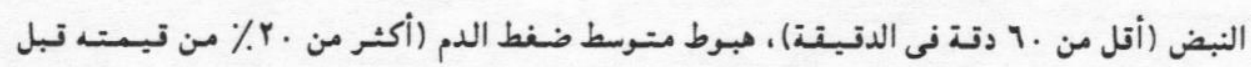

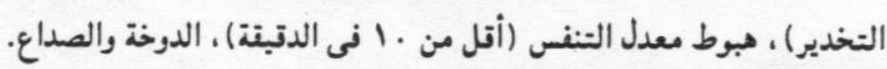

أظهرت نتانج هذه الدراسة التساوى بين مجموعتى المورفين والنيوستيجمين بالنسبة لمدة ودرجة تسكين الألم بعد العملبة، لكن وجدت فروق ذات دلالة إحصائبة بين كلا المجموعتين مقارنة بالمجمسوعة الحماكية.

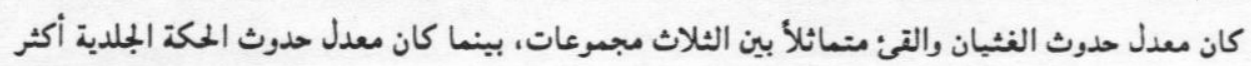

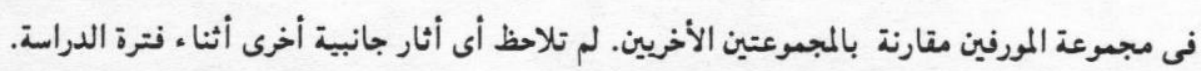
ما سبق يتضح أن إضانة جرعة صغيرة من عقار النيوستبجمين (0 ميكروجرام) مع عقار البيوبيناكين بالحقن تحت الأم العنكبوتبة تبدو مفيدة لتحسين مدة ودرجة تسكين الألم بعد عمليات جراحات العظام . 
